\title{
Oviposition, life cycle, and parasitoids of the spruce cone maggot, Strobilomyia anthracina (Diptera: Anthomyiidae), in the Alps
}

\author{
E.G. Brockerhoff* and M. Kenis \\ International Institute of Biological Control, European Station, 1 Chemin \\ des Grillons, 2800 Delémont, Switzerland
}

\begin{abstract}
The life cycle of Strobilomyin anthracina (Czerny) which exploits Norway spruce seed cones was investigated in 1992 and 1993 in the Alps at c. $1800 \mathrm{~m}$ at Torgnon (Valle d'Aosta, Italy) and Lac de Tseuzier (Valais, Switzerland) by sampling cones at fortnightly intervals. Oviposition occurred primarily singly in the basal third of cones at the beginning of June when cone scales were open for pollination. Infestation rates were higher when cone crops were poor. Most larvae left the cones in August to pupate in the litter beneath trees, usually at a depth of $1-4 \mathrm{~cm}$. Prolonged diapause of pupae coincided with failed or poor cone crops. Parasitism was investigated at these two and 27 additional sites in the Swiss, French and Italian Alps. Among several hundred host eggs only one was parasitized by Trichogramma sp. (Trichogrammatidae). Among the larval-pupal endoparasitoids, the figitid Sarothrus areolatus Hartig was more common than an ichneumonid, Atractodes sp., but parasitism by both was commonly below $10 \%$. Parasitism by an ichneumonid larval ectoparasitoid, Scambus sp., also rarely exceeded $10 \%$. Puparia of S. anthracina that were buried in the litter to detect pupal parasitoids revealed the gregarious pteromalid Tritneptis sp. near lophyrorum (Rushka). This is the first record of a pupal parasitoid of Strobilomyia species. Information on the biology of the three larval parasitoids is presented. The potential for biological control of North American Strobilomyia neanthracina Michelsen and S. appalachensis Michelsen by importation of natural enemies of S. anthracina appears limited.
\end{abstract}

\section{Introduction}

The recent development of seed orchards, to provide genetically superior seed for reforestation programmes, has increased concerns about seed losses to insect pests. Strobilomyia spp.(Diptera: Anthomyiidae), commonly known as cone maggots, are important pests of conifer seed cones and may destroy entire crops in Europe and North America (e.g. Stadnitzskii et al., 1978; Roques, 1983; Roques et al., 1984;

*Present address: Canadian Forest Service, Great Lakes Forestry Centre, PO Box 490, Sault Ste. Marie, Ontario, P6A $5 \mathrm{M} 7$, Canada. de Groot et al., 1994). All Strobilonyia species attack only one or a few conifer species of the same genus (Michelsen, 1988). Strobilomyia anthracina (Czerny) attacks cones of Norway spruce, Picea abies, in Europe and northern Asia (Stadnitzskii et al., 1978) and several other spruce species in eastern Asia (Suwa, 1971; Fang et al., 1989). Strobilomivia anthracina was believed to be a Holarctic species, but a review identified the North American spruce cone maggots as S. neantlracinn Michelsen and S. appalachensis Michelsen (Michelsen, 1988; Turgeon \& Sweeney, 1993).

Chemical means for control of cone maggots are available (e.g. Annila, 1973; Miller \& Hutcheson, 1981), but such treatments may have adverse environmental effects and 
require annual expenditure for control. Biological control could provide environmentally safe and long-lasting, and therefore potentially inexpensive control. Biocontrol programmes require detailed knowledge of the target species' biology and associated natural enemies. Some information on the biology of S. anthracina and its parasitoids is already available for parts of north-eastern Europe (Kangas \& Leskinen, 1943; Stadnitzskii et al., 1978; Annila, 1981), but for central Europe it is limited (e.g. Roques, 1983). In particular, oviposition has not previously been studied in detail, and there is no information on pupal parasitism. This manuscript presents additional information on the life history of 5 . anthracina and its parasitoids and a description of the phenological relationships of Norway spruce seed cones, cone maggots and parasitoids in Central Europe. The prospects for biological control of North American spruce cone maggots by introduction of natural enemies of S. anthracina are also discussed.

\section{Materials and methods}

This study was carried out in parts of the Swiss, French and Italian Alps (table 1). To investigate the phenology of $S$. anthracina and its parasitoids, cones of $P$. abies were collected at Torgnon and Tseuzier in 1992 and 1993, at fortnightly intervals from late May to the end of September. On each sampling date, cones were taken equally from five randomly selected trees per site, and trees were sampled once per year. Cones were collected systematically and evenly from all crown regions, either by climbing trees or, from smaller trees, with a pole pruner. From mid-July onwards, when infested cones became bent and resinous, only such cones were collected. Sample sizes per site ranged from 50 to 200 cones in 1992 and from 10 to 25 cones in 1993 , when cones were scarce. To study egg parasitism, additional samples of 50 cones were taken at the end of the oviposition period of S. anthracina at Martigny and San Bernardino in spring 1993. All cones were kept at $2^{\circ} \mathrm{C}$ and dissected within a few days. Length of cones was determined prior to dissection and all observations were categorized into longitudinal thirds. Eggs were reared in petri dishes kept inside plastic containers with moist paper until the larvae hatched or the parasitoids emerged. All larvae were dissected for parasitoids.

Table 1. Collection sites of Strobilomina anthracina, sample sizes and endoparasitism.

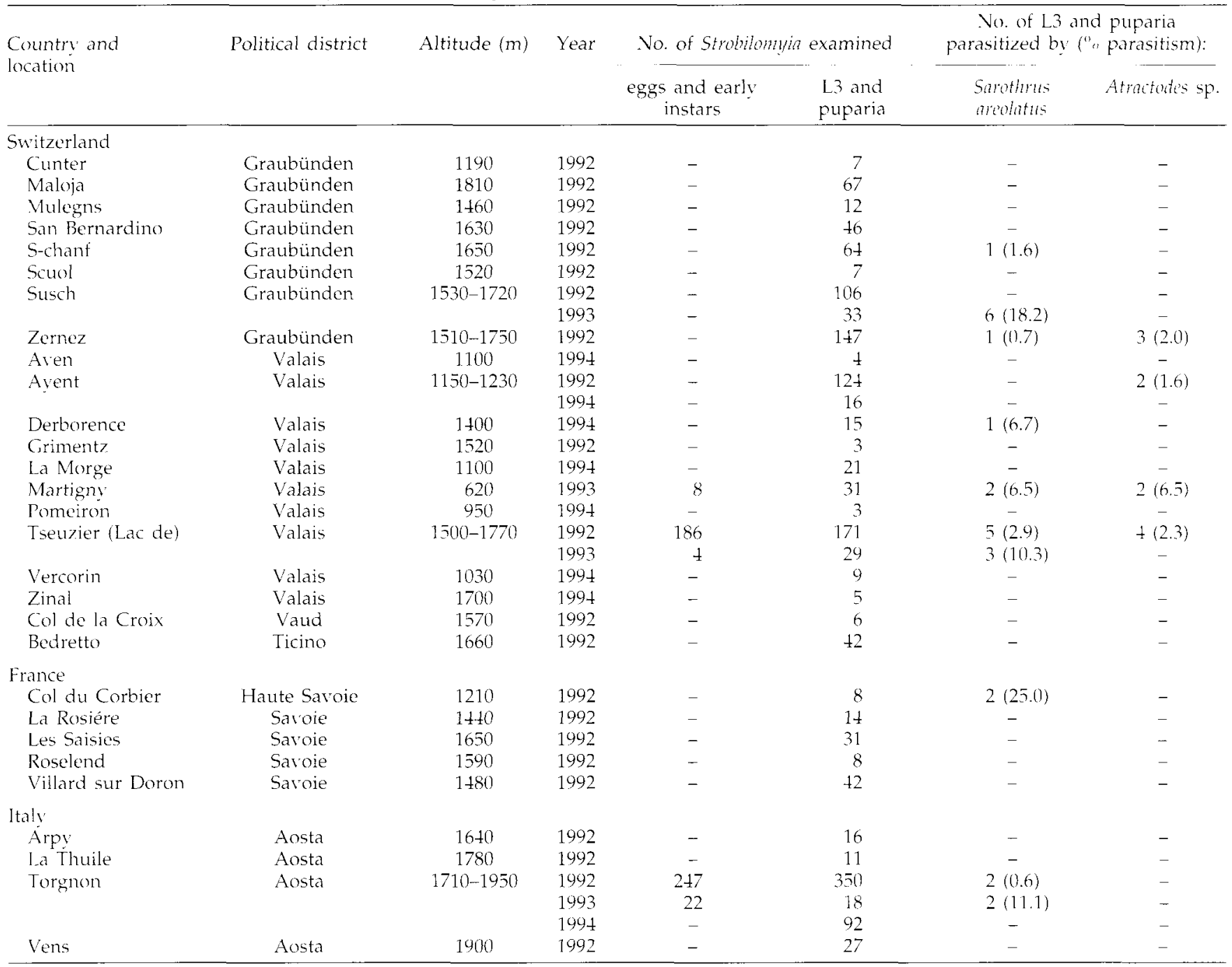


To study the abundance and distribution of the endoparasitoids of S. anthracina, a total of 4693 infested cones (at least 50 per site) was sampled at 22 sites in 1992, four sites in 1993 and at tight sites in 1994 (table 1). These samples were taken shortly before the larvae left the cones to pupate in the litter, i.e. between the end of June and mid-August, depending on stand elevation. Cones were placed on an $8 \mathrm{~mm}$ mesh screen over water-filled plastic travs into which the larrae dropped when they exited the cones. Twice a dav, larvae were removed from the travs and put on moist sifted soil in which they pupated. To assess mortality and parasitism, all puparia were dipped into water. This makes them translucent and easier to examine with a stereo microscope. (Healthy, dead or parasitized puparia contain either whitish pupae, an amorphous substance or air, or parasitoid larvae, respectively.) Puparia were overwintered outside in clay pots filled with sifted soil and covered with gauze $(0.3 \mathrm{~mm}$ mesh) for protection from predators, but not from moisture. The following spring, all puparia were sifted from the soil, placed in petri dishes and allowed to complete their development in the laboratory. Unhatched puparia were re-examined to assess mortality that had occurred during overwintering.

At all collection sites, the size of the cone crop was recorded, using binoculars if necessary. For each stand, the number of seed cones per tree was counted or, if cone crops were high, estimated. The mean of at least ten trees was used to assign cone crops to one of four classes of cone production: none ( 0 cones per tree), low (1-10 cones per tree), medium (10-100 cones per tree), and high (more than 100 cones per tree).

Larval ectoparasitism was studied at Tseuzier and Torgnon in 1992 and 1993 and at Martigny in 1993 and calculated as follows: "\%, ectoparasitism = no. of parasitized larvae/(total no, of larvae + no. of empty tunnels). As ectoparasitoids kill cone maggots before they can exit the cone, those that had left the cones to pupate in the litter (i.e. empty tunnels) were included in the total number of hosts.

Depth of pupation of $S$. anthracina was determined by placing c. 200 mature larvae onto moistened sifted soil in an $11 \mathrm{~cm}$ diameter plastic container buried outside in the ground. After pupation, layers of $1 \mathrm{~cm}$ were sifted to a depth of $24 \mathrm{~cm}$ to recover the puparia.

To investigate pupal parasitism and predation, a total of 527 mature larvae or fresh puparia were exposed at several sites (between 50 and 148 per site) $c .1 \mathrm{~cm}$ deep in wooden cages $(30 \times 30 \times 5 \mathrm{~cm})$ filled with sifted soil. Cages with a screen bottom ( $2 \mathrm{~mm}$ mesh) and top ( $8 \mathrm{~mm}$ mesh) to exclude vertebrate predators, were buried underneath spruce trees and covered with a $2 \mathrm{~cm}$ layer of forest litter. From September 1992 to April 1993, S. anthracina were exposed at Torgnon and Tseuzier and then transferred to the laboratory for emergence. Puparia were also exposed from July/August to September at Ayent in 1994 and 1995 and at Tseuzier in 1995. Additionally, puparia were extracted from five samples of forest litter and humus $(50 \times 50 \mathrm{~cm}, 10 \mathrm{~cm}$ deep) taken under infested trees at Tseuzier in September 1993 by sifting or soaking the samples in water.

Terminology for descriptions of parasitoid larvae is according to Short (1959) and Hagen (1964). Statistical analysis was performed using SYSTAT 5.03 for Windows ${ }^{\text {TM }}$ or generated by hand. The frequency distribution of eggs was determined by goodness-of-fit comparison with a
Poisson distribution (Ludwig \& Revnolds, 1988). If it deviated significantly, the index of dispersion and the d-statistic were calculated (Ludwig \& Reynolds, 1988) to determine whether the distribution was clumped or regular.

\section{Results and discussion}

\section{Oeiposition and life chele}

The emergence of adult S. antiracina was not determined in the field, but they were observed flying around spruces and ovipositing in late May at Torgnon. The phenology presented (fig. 1) refers to observations made at Torgnon in 1992. The phenology was similar at Tseuzier in 1992, but in 1993 larral exit was already complete by mid-August at both Torgnon and Tseuzier (Brockerhoff, 1994). Strobilomyin anthracinn oviposited between the cone scales of Norway spruce from late May onwards, usually when the scales were open.

Almost $70 \%$ of $S$. anthracina eggs were laid in the basal third of cones, none were found in the apical third (fig. 2). Single eggs were most common in infested cones (fig. 3), but when the cone crop was low, cones contained up to six S. anthracina eggs (1993 at Martigny). At Torgnon, eggs were not Poisson distributed $\left(y^{2}=8.56,2 \mathrm{df}, P<0.01\right)$ but had been laid regularly (index of dispersion $=0.74, \mathrm{~d}$-statistic $=-2.84$, $P<0.01$ ). However, at Tseuzier the frequency distribution did not significantly deviate from a Poisson distribution $\left(\chi^{2} 4.73,1 \mathrm{df}, 0.1>P>0.05\right)$. Single eggs were also most common in cones of Picea mariana attacked by $S$. appalachonsis (Sweeney \& Turgeon, 1994). Such regular oviposition may be due to an oviposition deterring pheromone (Sweeney \& Turgeon, 1994) which reduces intraspecific competition.

Infestation rates, determined at the end of the oviposition period, appeared to be negatively correlated with the level of cone production. In 1992, when the cone crop was high at all sample sites, $35 \%$ of the cones $(n=350)$ were infested by $S$. anthracina at Torgnon, and $50 \%$ at Tseuzier $(n=200)$. In 1993 , when cones were scarce, $58 \%$ were infested at Torgnon $\left(n=50, z^{2}=10.0, P=0.002\right)$, and $89 \%$ at Tseuzier $(n=35$, $y^{2}=18.0, P<0.0001$ ). Maximum infestation rates (S. anthracind per cone \pm S.D.) were $0.41 \pm 0.55$ and $0.8 \pm 0.8$ at Torgnon and $0.83 \pm 0.97$ and $1.3 \pm 0.8$ at Tseuzier during 1992 and 1993, respectively.

First instar S. anthracina remained in the egg and larvae emerged as second instars. This was first observed by Tripp (1954) for S. meantlimacina in North America. The larvae fed spirally around the cone axis destroying scale tissues and developing seed, and by the beginning of July, the majority were third instars (fig. 1). By mid-July, infested cones were readily identified as being typically bent and intensively resinous. Drops of brown frass-containing resin oozed from a hole made by the larva along the concave side of the cone bend. At the end of July, larvae began leaving the cones to pupate in the litter where they overwintered (fig. 1). Most larvae had left the cones by late August, but at Torgnon, a few larvae were found in cones until the end of September. Larvae usually exit during rain (Annila, 1981), which may reduce the risk of larval desiccation and predator attack (Sweeney \& Turgeon, 1994) and may moreover assist entry into the litter.

Most larvae (two thirds) pupated at a depth of $1-4 \mathrm{~cm}$, but some were found as deep as $8-9 \mathrm{~cm}$ (fig. 4). This distribution agrees with field observations obtained from 


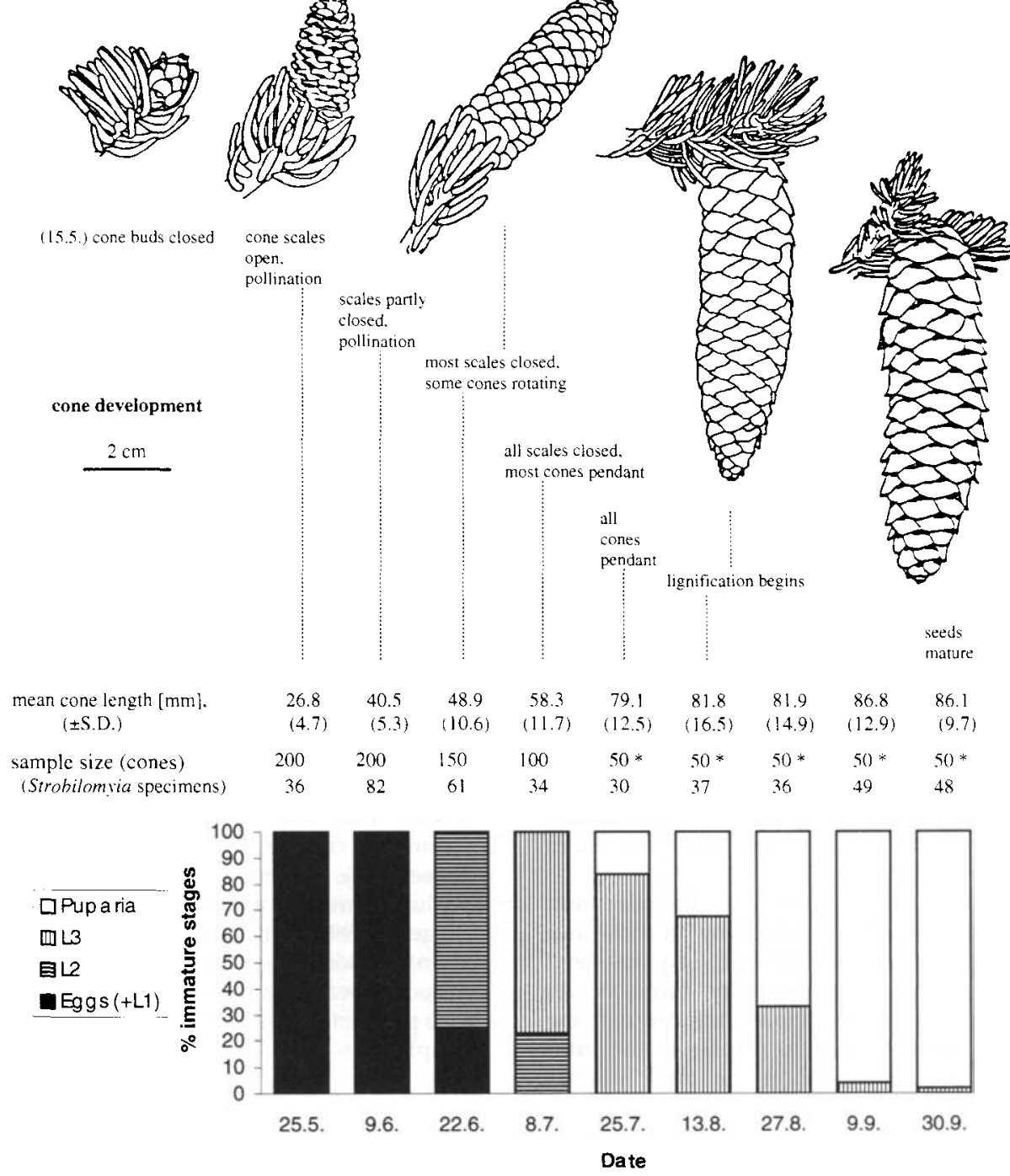

Fig. 1. Development of Picen abies cones and life cycle of Strobilomyin anthracinn at Torgnon in 1992, indicating the percentage of eggs, larval instars and puparia. The latter have been determined by the presence of empty tunnels. ${ }^{*}$ from 25 July on, only $S$. anthracina infested cones were sampled.

litter and soil samples. (This method is not recommended for collecting puparia, because only two to six were found per $0.1 \mathrm{~m}^{3}$ litter and humus, and the recovery process was impeded by large quantities of spruce needles and pieces of

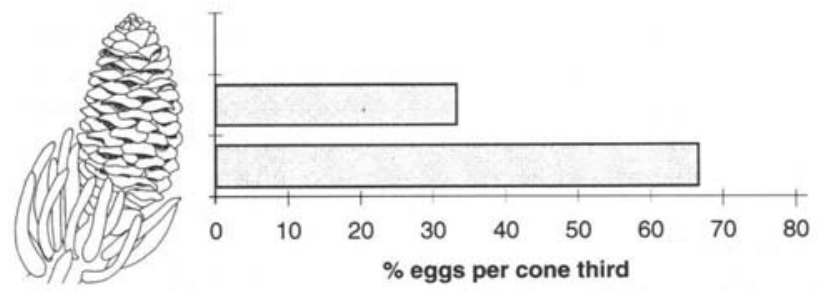

Fig. 2. Longitudinal distribution of eggs of Strobilomyia anthracina in spruce cones at Torgnon, 9 June $1992(\mathrm{n}=200$ cones, 82 eggs).

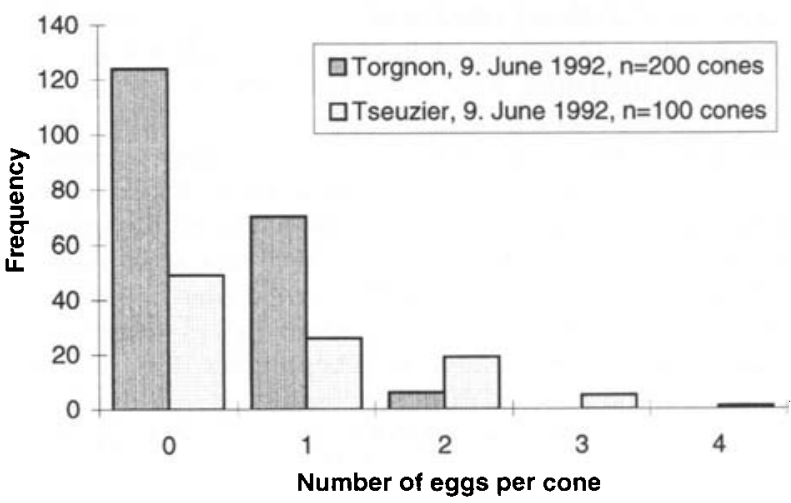

Fig. 3. Frequency distribution of Strobilomyin anthrainn eggs at two sites. 
Number of puparia

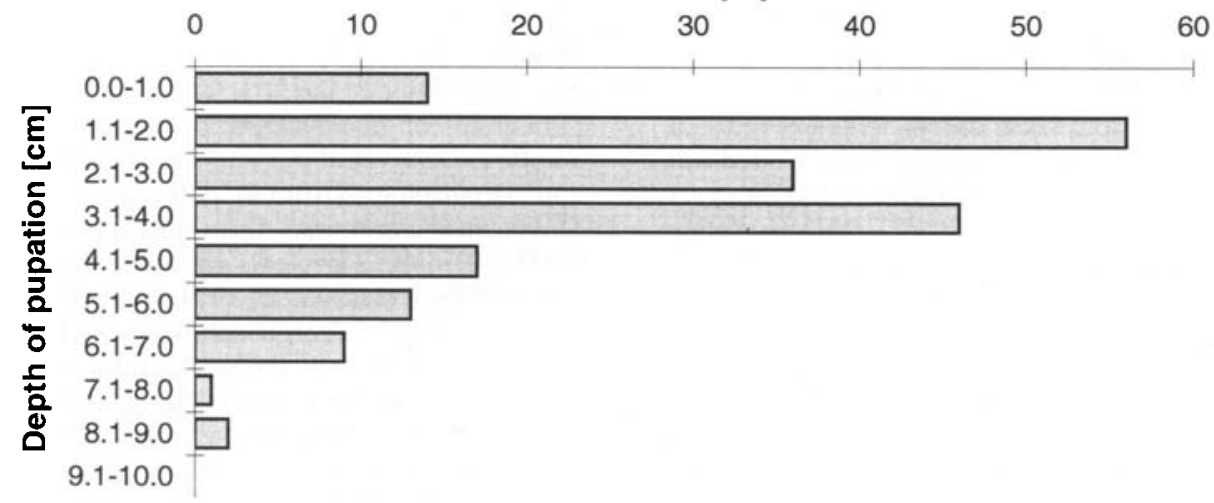

Fig. 4. Frequency distribution of Strobilomylin anthracina puparia in a soil layer of $10 \mathrm{~cm}$ depth $(\mathrm{n}=191)$.

wood.) Similarly, Fogal (1986) found most puparia in the upper soil horizons.

Pupation occurred within a few davs after the puparium was formed. Adults emerge either the following spring, at Torgnon and Tseuzier around early May, or stay in prolonged diapause. Annila (1981) observed prolonged diapause lasting up to two years. In our samples, $67-100 \%$ of Strobilomyia from 1992 and 1993 remained in diapause the following vear, when the cone crop was rated 'none' or 'low.' Among Strobilomyin from 1994, only 0-20\% remained in diapause during 1995, when cone production was 'medium' at all sampling locations. Puparia that overwintered at the collection sites in exposure cages or in clay pots outside the laboratory had equal rates of prolonged diapause for Tseuzier but differed slightly for Torgnon (table 2). Overall, there was little difference between the two groups which suggests that the diapause behaviour had been determined prior to overwintering and overwintering in the laboratory vard did not alter it greatly. Prolonged diapause is frequently observed in conophytes (insects that feed exclusively on cone

Table 2. Comparison of mortality and prolonged diapause of Strobilonyia anthracina puparia from 1992 overwintered at the collection sites Tseuzier and Torgnon (altitudes $1770 \mathrm{~m}$ and $1800 \mathrm{~m}$, respectively) and at the laboratory in Delémont (altitude $500 \mathrm{~m}$ ) under semi-natural conditions.

\begin{tabular}{lcccc}
$\begin{array}{l}\text { Origin of } \\
\text { puparia }\end{array}$ & $\begin{array}{c}\text { Overwintering } \\
\text { location }\end{array}$ & $\begin{array}{c}\text { Overwintering } \\
\text { mortality }\left({ }^{\circ}\right)^{*}\end{array}$ & $\begin{array}{c}\text { Number of live } \\
\text { puparia after } \\
\text { overwintering }\end{array}$ & $\begin{array}{c}\% \text { in prolonged } \\
\text { diapause after } \\
\text { one winter }\end{array}$ \\
\hline Tseuzier & Tseuzier & 41 & 38 & 100 \\
\multirow{2}{*}{ Torgnon } & Delémont & $9^{* * *}$ & 73 & 100 \\
& Torgnon & 38 & 79 & 92 \\
\hline
\end{tabular}

"Chi-square test of mortality between samples from the same origin $\left.{ }^{* * *}, P<0.001\right)$.

"Fisher's exact test of diapause rates between samples from same origin $(* *, P<0.01)$

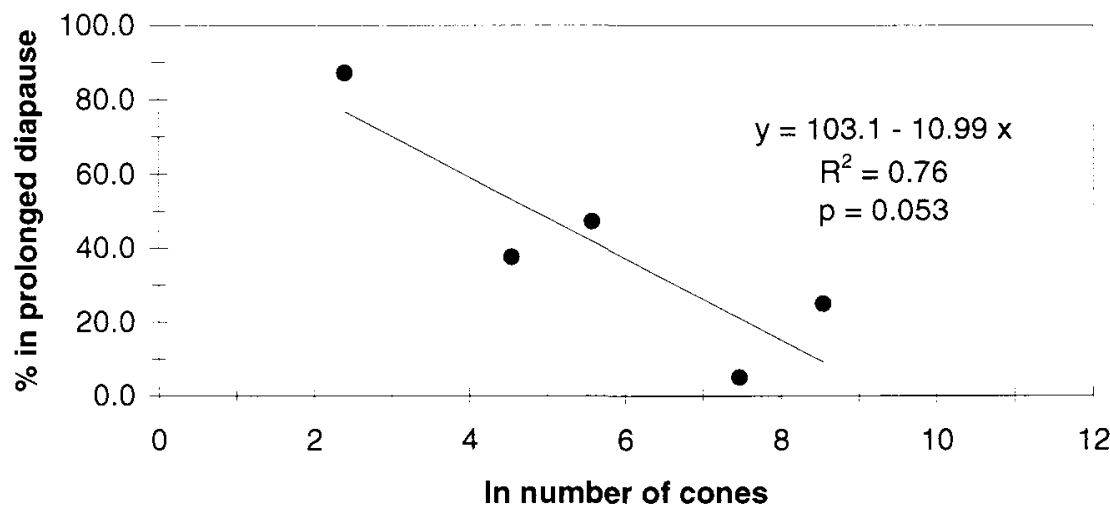

Fig. 5. Relationship between the percentage of Strobilontyin anthracina remaining in diapause for more than one vear (i.e. in prolonged diapause) and the abundance of cones in the year following larval development (number of cones ln transformed). Data after Annila (1981). 
structures; sensil Turgeon of al., 1994), and is understood to be an adaptation to temporal fluctuations in the level of cone production (Bakke, 1963; Hanski, 1989; Roques, 1989).

In our samples, the occurrence of prolonged diapause coincided with failed or low cone crops, whereas rates of prolonged diapause were low when there was a medium cone crop. Similarly, data provided by Annila (1981) suggest that diapause is, to some degree, correlated with actual cone production, at least after the first overwintering (fig. 5). Hanski (1989) suggested that conospermatophages (insects feeding on both cones and seeds; sensu Turgeon et al., 1994), like Strobilomili spp., use 'risk spreading diapause', in which the length of diapause of the progeny of oripositing females raries over several years within one generation. This would ensure that at least some of the offspring find cones for oviposition. However, we suggest that $S$. anthmina uses 'predictive diapause' rather than 'risk spreading diapause'. Predictive diapause was defined by Hanski (1989) for spermatophages (insects feeding only on seeds; sensu Turgeon of al., 1994) that show a correlation between prolonged diapause and a lack of oviposition sites. It is clear that the correlation between conophyte emergence and presence of cones becomes weaker the longer the diapause lasts. Strobilomyia species are very likely to have difficulties adjusting their emergence to cone crops after more than one year, because they diapause in the litter where they are protected from cues provided either directly by the tree or by external factors (see Roques, 1989, for a discussion of probable mechanisms of diapause induction).

\section{Parasitoids}

Three specimens of a Trichogramma sp. (Hymenoptera: Trichogrammatidae) developed in a single $S$. anthracino egg collected at Martigny in late May $1993(n=50)$. Identification to the species level was not possible as only females emerged (identification is based on male characters). Many similar looking specimens were obtained from the same and other cones collected at Martigny, Torgnon and Tseuzier, but only from eggs of Cydia strobilella (Linnaeus) (Lepidoptera: Tortricidae) (Brockerhoff \& Kenis, 1996), although several hundred eggs of $S$. antlmacina were present. This is the first record of an egg parasitoid of S. antluracina.

Parasitism by other guilds was low, especially in 1992, when cones were very abundant (tables 1 and 3). Larvalpupal endoparasitoids were not found at two thirds of the sites, but some sample sizes may have been too small. Parasitism was higher in samples from 1993, when the cone crop was very low and the number of Strobilomyia per cone had increased, but the few cones available limited the sample sizes (tables 1 and 3). An inverse relationship of parasitism rate and cone crop has also been reported for $S$. melanim Ackland (Roques, 1988).

Sarothms areolatus Hartig (Hymenoptera: Figitidae), a larval-pupal endoparasitoid, was found at one third of the sites (table 1). Eggs and the characteristic eucoiliform first instar were found in third instars in July at Tseuzier. However, in North America, Sarothrus sp. (parasitizing Strobilomyin neanthracina) were observed attacking host eggs (Brockerhoff, unpublished data). Parasitized larvae developed normally and left the cones to pupate in the litter. Then, the parasitoid larva immediately consumed the host pupa externally while still remaining in the puparium. The mature larva is hymenopteriform ('grub-like'). After pupation in spring, the parasitoid chewed a hole through the puparium and emerged, in the laboratory, two to four weeks after the host. Several specimens stayed in prolonged diapause for one year. This is the first record of Sorothrus arolatus as parasitoid of Strobilomyia anthracina, but other figitids, Sarothrus abietis Belizin, Sarothrus sp. (Stadnitzskii ot al., 1978) and Molanips sp. (Annila, 1981), have been reported from Strobilomyia anthracina from north-eastern Europe. Other hosts of Sarothrus areolatus are the anthomyids Pegolulemyia Shava Meigen (Harwood, 1919; Wille, 1930; Blair, 1946) and P. sonchi (Hardy) (Fergusson, 1986; Kählert, 1990).

An Atractodes sp. (Hymenoptera: Ichneumonidae) was rare in our samples (table 1). It could not be identified with certainty, but is probably A. scutellatus Hellén, a species known to parasitize Strobilomia anthracina (Kangas \& Leskinen, 1943; Stadnitzskii it al., 1978). The phenology was identical to that of Sarothms arolatus. First instars are caudate and mature larvae are hymenopteriform. Some specimens stayed in prolonged diapause for at least two vears.

A Scambus sp. (Hymenoptera: lchneumonidae) was found at all sites investigated for ectoparasitism (table 3). Identification was not possible because the larvae could not be reared to adults, but the cephalic structure indicated that it was a Scombus sp. (Short, 1959). It is most likely to be S. strobilonum Ratzeburg [ = S. sagax var. laticops (Ratzeburg)] which we often reared from infested spruce cones. Parasitisation of third instars paralysed before oviposition commenced between late May (Martigny) and July (Torgnon, Tseuzier). The parasitoid larva consumed its host within a few days and spun a cocoon within the tunnel made by the cone maggot. Adults emerged between April and May from cones kept outside (Brockerhoff \& Kenis 1996). Other hosts of S. strobilorm are the pyralid Dioryctrin abietella Fabricius (Stadnitzskii et al., 1978), the tortricid Petrow resinello Linnaeus (Györfi, 1939, 1941) and the anobiid Emobius abietis Fabricius (Györfi in Herting, 1973).

Tritneptis sp. near lophyronm (Hymenoptera: Pteromalidae) was reared from Strobilomyia anthincinn exposed at Ayent in 1994. This is the first record of a pupal parasitoid of Strobilomyia spp. Eight females and one male emerged from each of only two parasitized puparia, but this parasitoid might be more common since the exposure method was not exactly natural. Tritileptis spp. are usually associated with sawfly cocoons (Graham, 1969). Predation of cone maggots on the ground and puparia in the soil might also be important. In 1992, 1994 and 1995, we recovered only 63,92 and $85 \%$, respectively, of the puparia buried in the soil, the rest were probably preyed upon by invertebrates.

Recommendations for the biological control of North American S. neanthracinn and S. appalachensis by introduction of natural enemies of $S$. antimacina cannot be made yet, because the natural enemies of North American Strobilomilia

Table 3. Ectoparasitism of Strobilomyin anthracina by Sambus sp. at three sites.

\begin{tabular}{|c|c|c|c|c|}
\hline \multirow[t]{2}{*}{ Location } & \multicolumn{2}{|r|}{1992} & \multicolumn{2}{|r|}{1993} \\
\hline & $\mathrm{V}$ & No. parasitized & $N$ & No. parasitized \\
\hline Tseuzier & 230 & $1\left(0.4^{\circ}\right)$ & 19 & $2\left(10.5^{\circ}{ }_{0}\right)$ \\
\hline Martigny & - & - & 35 & $5\left(1+.3^{\prime \prime} 0\right)$ \\
\hline Torgnon & 175 & $8\left(4.6^{\circ} i\right)$ & 16 & $1\left(6.3^{10}{ }^{10}\right)$ \\
\hline
\end{tabular}


are only now being investigated. Based on the low levels of parasitism observed in this study, the prospects for biocontrol appear rather limited. However, higher parasitism rates of $S$, anthracina were reported from Finland and the former Soviet Lnion where endoparasitism alone reached up to 70". (Stadnitzskii et al., 1978; Annila, 1981). A braconid larral endoparasitoid Phanocarpa sp. (Stadnitzskii if al., 1978) and a predator, Earomuin schistopugn Collin (Diptera: Lonchaeidae), (Kangas \& Leskinen, 1943; Hackman, 1956), natural enemies of 5 . anthracina not encountered by us, could also be evaluated for biocontrol. However, preliminary results fron North America (Brockerhoff, unpublished) suggest that the larral parasitoid complexes of S. neanthracina and S. appolachensis are similar to that of 5. mithrim, with identical or closely related species. The potential for biological control by predators and pupal parasitoids remains to be determined.

\section{Acknowledgements}

We thank A. Brockerhotf, K. Kock, S. Leroy, C. LopezVaamonde, N. Otten, A. Raps, A. Van Arerbeke and D. You for field and laboratory support and Drs X.D.M. Fergusson, K. Horstmann, D.R. Kasparyan, B. Pintureau and S. Vidal who kindly identified the parasitoids (roucher specimens are deposited at the IIBC laboratory, Delémont, Switzerland). We also thank Drs J.S. Badmin, J.D. Sweeney and J.J. Turgeon and two anonymous reviewers for suggesting improvements to the manuscript and the Canadian Forest Service for financial support.

\section{References}

Annila, E. (1473) Chemical control of spruce cone insects in seed orchards. Commumicationes bistituti Forestalis Fenmine 78 , $1-24$

Annila, E. (1981) Fluctuations in cone and seed insect populations in Norray spruce. Communicationes instituti Forestalis Fonmiar 101, 1-32 (in Finnish, with English summary).

Bakke, A. (1963) Studies on the spruce-cone insects Laspeypesin strobililia (L.) (Lepidoptera: Tortricidae), Kiltenthichola strohi (Winn.) (Diptera: Itonidae) and their parasites (tymenoptera) in Corway. Meddelelser fin det Norske' skopstorsoksectsen 19, 1-151

Blair, K.G. (1946) Sarothrus arohluts Hart. (Hym., Cynipidae) at Wimbledon. Entomolowist's Monthly Maya-ine 82, 21

Brockerhoff, E.G. (1994) Okolocische Stutien an anfenbewolmenten lnsikten der Fichte (Picea abies IL.I Karst.)

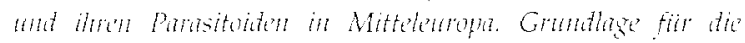
biohorishe Bekimpfung conophage Forstschadlinge in Kanata. 106 pp. Kiel, Germany, Diplomarbeit, Lniversität Kiel.

Brockerhoff, E.G. \& Kenis, M. (1996) Parasitoids associated with Cydili strolilella (L.) (Lepidoptera: Tortricidae) in Europe, and considerations for their use for biological control in North America. Biological Control 6, 202-214.

de Groot, P., Turgeon, J.J. \& Miller, G.E. (1994) Status of cone and seect insect pest mandgement in Canadian seed orchards. Forestry Chronicle 70, 745-761.

Fang, S.-Y., Roques, A. \& Sun, J.-H. (1989) Result of a survey of cone and seed insects in some conifer forests of northeast China. pp. 2-11 in Miller, G.E. (E.t.) Procedtings

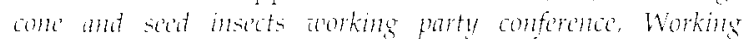
Party 52.07-01, MLFRO, 26-30 Inhe 1988; Victorila, BC,
Cinadn. Victoria, BC, Forestry Canada, Pacific Forestry Centre.

Fergusson, N.D.M. (1986) Charipidae, Ibaliidae \& Figitidae. Hymenoptera: Cynipoidea. pp. 1-55 in Barnard, P.C. \& Askew, R.R. (Eds) Handbooks for the identification of Britisit insects. Vol. 8, Part 1c. London, UK, Roval Entomological Society of London.

Fogal, W.H. (1986) Applying Benuerin businum (Bals.) Vuill. to soil for control of the spruce cone maggot Lasionmmi anthracin (Czerny). pp. 257-266 in Roques, A. (Et.) Procedings 2 nd conference cone and seed insets working furty S2.07-01. Brimicon, France, September 3-5, $1980^{\circ}$ Ardon, Olivet, France, Station de Zoologie Forestiere, INRA-CRF.

Graham, M.W.R. de V. (1969) Pteromalidae of north-western Europe (Himenoptera: Chalcidoidea). Bulletin of the British Museum Catural Histony. Entomology Supplement $16,1-908$

Györfi, J. (1939) Beiträge zur forstlichen Bedeutung der Schluptrespen. Erdesziti kiserletek 41, 117-2+2 (in Hungarian, with German summary).

Györfi, J. (1941) Die Ephialtesarten Ungarns. Erdeszeti kiserletek $43,242-249$.

Hackman, W. (1956) The Lonchaeidae (Dipt.) of eastern Fennoskandia. Notulac Entomologicae 36, 89-115.

Hagen, K.S. (1964) Dexelopmental stages of parasites. Pp. $168-$ 246 in DeBach, P. (Ed.) Biological control of insect pests and weets. New York, Reinhold Publishing Corp.

Hanski, I. (1989) Prolonged diapause: theory and obserrations. pp. 91-100 in Miller, G.E. (Ed.) Procedings cone and seed insects working party conference, Working Porty S2.07-01. IUFRO, 26-30 Jume 1988; Victoria, BC, Camada. Victoria, BC, Forestry Canada, Pacific Forestry Centre.

Harwood, B.S. (1919) Sarothrus areolatis Htg. bred. Entomolegist's Monthly Magnaine 60, 280 .

Herting, B. (1973) A catalogte of parasites and pretators of terrestrial arthropots, section A, host or protentemi, Vol. 3. Coleoptera to Strepsiptern. $185 \mathrm{pp}$. Slough, UK, Commonwealth Agriculture Bureaux.

Kählert, A. (1990) Die Blitenkopfleweohner dè Ginssedistel (Sonchus spp., whi ihn Pamsiten. 72 pp. Kiel, Germany, Diplomarbeit, Lniversität Kiel.

Kangas, E. \& Leskinen, K. (1943) Pegohylemyia anthracina Czerny (Dipt., Muscidae) als Zapfenschädling an der Fichte. Anmales Fntomologici Fonnici 9, 195-212.

Ludwig, J.A. \& Reynolds, J.F. (1988) Stntistical cology. 337 Pp. New York, John Wiley \& Sons.

Michelsen, V. (1988) A world revision of Strobiloming gen . n.: the anthomyiid seed pests of conifers (Diptera: Anthomyidae) Sustematic Entomology 13, 271-314.

Miller, G.E. \& Hutcheson, D.W. (1981) Aerial spraying for control of the spiral spruce-cone borer, Hylemina antinacina (Diptera: Anthomyiidae). Joumal of the Entomoloyical Societly of British Columbin 78, 3-6.

Roques, A. (1983) Les insectes mingent des contes of grames de confere's en France. 134 pp. Parts, INRA.

Roques, A. (1988) The larch cone fly in the French Alps. pp. 1-28 in Berryman, A.A. (Ed.) Dumainics of forest insect poptudations. New York, Plenum Publishing Corporation.

Roques, A. (1989) New results and some thinkings about significance and induction of prolonged diapause in cone insects with particular references to the larch cone fly (Lasiomma melania) and to the Douglas-fir seed chalcid (Megasticnuts spormotrophus). pp. 64-81 in Miller, G.E. (F.t.) 
Procedings cone and seed insects working party conference, Working Party S2.07-01, IUFRO, 26-30 Jwne 1988; Victoria, BC, Canata. Victoria, BC, Forestry Canada, Pacific Forestry Centre.

Roques, A., Raimbault, J.P. \& Delplanque, A. (1984) Les diptères Anthomviidae du genre Lisiomma Stein. ravageurs des cones et graines de mélèze d'Europe (Larix decidua Mill.) en France. II. Cycles biologiques et dégâts. Zeitsclirift fiir Angerundte Entoniologie 98, 350-367.

Short, J.R.T. (1959) A description and classification of the final instar larvae of the Ichneumonidae (Insecta: Hymenoptera). Proceedings of the United States National Museum 110 391-511.

Stadnitzskii, G.W., Jurcenko, G.I., Smetanin, A.N., Grebenstsikova, V.P. \& Pribylova, M.V. (1978) Cone and seed pests of conifers. $164 \mathrm{pp}$. Moscow, Russia, Lesnaia promyshlennost (in Russian).

Suwa, M. (1971) Notes on the genus Lasiomma Stein in Japan, with descriptions of two new species (Diptera: Anthomyiidae). Kontun 39, 28-36

Sweeney, J.D. \& Turgeon, J.J. (1994) Life cycle and phenology of a cone maggot, Strobilomyia appalachensis Michelsen
(Diptera: Anthomyiidae), on black spruce, Pica mariana (Mill.) B.S.P., in eastern Canada. Conndian Entonologist 126, $49-59$.

Tripp, H.A. (1954) The instars of a maggot (Pegohlylemilin) inhabiting white spruce cones. Camatian Entomologist 86, 185-189.

Turgeon, J.J., Roques, A. \& de Groot, P. (1994) Insect fauna of coniferous seed cones: diversitv, host plant interactions, and management. Ammual Rerilew of Entomology $39,179-212$

Turgeon, J.J. \& Sweeney, J.D. (1993) Hosts and distribution of spruce cone maggots (Strobilomilia spp.) (Diptera: Anthomyiidae) and first record of Strobilomyin appalachensis Michelsen in Canada. Comadian Entomologist 125, 637642.

Wille, J. (1930) Die Lattichfliege, Chortophila smara Meig., ein Grosschädling des Salatsamenbaus. Dic Gartenbantissenschaft 3, 127-184.

(Accepted 22 April 1997) - CAB INTER VATIONAL, 1997 